\title{
Formação dos partidos políticos no Brasil da Regência à Conciliação, 1831-1857
}

Brazilian Party Formation from

the Regency to the Conciliation, 1831-1857

\author{
Jeffrey D. Needell \\ Professor no Departamento de \\ História da Universidade da Flórida \\ (College of Liberal Arts \& Sciences/ \\ UF - Flórida/EUA) \\ e-mail: jneedell@ @istory.ufl.edu
}

\section{Resumo}

Os partidos se originaram de facções da Câmara lideradas por oradores que representavam oligarquias rurais e comerciais, bem como grupos urbanos mobilizados. Suas origens, evidentes na Assembléia Constituinte de 1823, consolidaram-se na "oposição liberal" de 1826-31. A maioria moderada dominou os primeiros anos da Regência, mas dividiu-se a respeito do aprofundamento da reforma liberal. Um movimento de reação levou a um novo partido majoritário em 1837, privilegiando um estado forte equilibrado com parlamento e gabinete representativos. Esse partido, posteriormente conhecido como os Conservadores, enfrentou uma oposição, depois conhecida como os Liberais que, embora compartilhassem algumas crenças liberais, inicialmente compuseram uma aliança de ocasião. Após assumir o poder, o imperador, que se mostrou desconfiado das lealdades e ambições partidárias, passou a dominar progressivamente o gabinete, aumentando seu poder, limitando os partidos e o parlamento e aumentando a autonomia do Estado, como se percebe na Conciliação e em sua herdeira, a Liga Progressista. Essas tensões explicam o significado da crise política de 1868, da Lei do Ventre Livre de 1871 e do legado de ceticismo para com o governo representativo que se seguiu.

\footnotetext{
Abstract

The parties derived from Chamber factions, led by orators representing the planting and commercial oligarchies and mobilized urban groups. The antecedents, clear in the 1823 Constituent Assembly, crystallize in the "liberal opposition" of 1826-31. The moderate majority dominated the first years of the Regency, but divided over more radical liberal reform. A reactionary movement led to a new majority party in 1837, emphasizing a strong state balanced by a representative parliament and cabinet. This party, eventually known as the Conservatives, faced an opposition, eventually known as the Liberals, who, while sharing some liberal beliefs, initially comprised an alliance of opportunity. After the emperor took power, he proved suspicious of partisan loyalties and ambitions, and increasingly dominated the cabinet, enhancing its power, undercutting the parties and parliament, and increasing state autonomy, as demonstrated in the Conciliação and its heir, the Liga Progressista. These tensions explain the meaning of the political crises of 1868 and the 1871 Lei de Ventre Livre and the legacy of cynicism over representative government which followed.
} 


\section{Palavras-chave}

práticas políticas, monarquia, escravidão, poder legislativo, debates parlamentares, liberalismo

\section{Keywords}

political practices, monarchy, slavery, legislative power, parliamentary debates, liberalism 
Eu tive a grande honra de ser convidado a apresentar um texto sobre as origens partidárias durante a Monarquia, uma honra decorrente da publicação de The Party of Order: The Conservatives, the State, and Slavery in the Brazilian Monarchy, 1831-1871. Stanford: Stanford University, 2006. Dadas as circunstâncias, peço a compreensão do leitor em relação às notas. 0 texto foi retirado de uma das abordagens de que tratei em mais de quatro capítulos de texto e aproximadamente sessenta páginas de notas. Como as contribuições que fiz à historiografia desse periodo baseiam-se na análise de fontes arquivisticas ou publicações coevas, achei melhor me limitar a séries selecionadas de notas retiradas dessas fontes, exceto quando a referência direta a fontes publicadas parece estritamente necessária. Existe considerável discussão historiográfica em The Party of Order; recomendo, portanto, que os mais interessados em tais debates consultem a obra. Todas as fontes da época estão citadas na ortografia original. Por favor, observe que, em referência à historiografia mais recente, minha pesquisa e meus trabalhos nessa área foram feitos entre 1997 e 2003, quando enviei o manuscrito para a editora e me dediquei apenas à revisão. Há muitos trabalhos publicados desde então que me teriam sido úteis na elaboração desse trabalho.

2

0 papel e os direitos dos partidos da maioria e da minoria, suas relações com o gabinete etc., podem ser observados nos calorosos debatas da Câmara em 1831 e 1832; ver, por exemplo, Hollanda. Annaes do parlamento brazileiro: Camara dos Srs. Deputados. (1876-1884). Tomo II. Rio de Janeiro: Hypolito José Pinto et al., 30 de agosto de 1831. p.50; Ribeiro de Andrada. Annaes do parlamento brazileiro: Camara dos Srs. Deputados. (18761884). Tomo I. Rio de Janeiro: Hypolito José Pinto et al., 15 de maio, 1832, p.165; 17 de maio, 1832, p.171e p.173. Os últimos discursos estavam relacionados às então recentes ameaças ao gabinete e às acusações de conspiração e de golpes restauracionistas.

3

[Eusébio] a [desconhecido, Rio], 24 de abril de 1849. Arquivo Nacional [daqui em diante, AN], AP07, caixa 9, pacote 1, PM 2082; [Eusébio] a Ribeiro, Rio, 15 de março de 1852. Arquivo Nacional, caixa 5, pacote 2, PM 1281.

4

Essa parte de minha análise está baseada mais em sinteses de outros trabalhos do que em pesquisa em arquivo, pois se refere a um período anterior ao de meu objeto de estudo em particular.

5

NEEDELL, Jeffrey D. Provincial Origins of the Brazilian state: Rio de Janeiro, the Monarchy, and National Political Organization, 1808-1853. Latin American Research Review, vol. 36, n.3, p.132-153, especialmente, p.138-139, 2001.
A natureza de um partido político precisa ser discutida como um prefácio aos problemas das origens partidárias no Brasil. ${ }^{1}$ Deve-se recordar que, para os atores políticos pós-independência, não havia histórico de partidos parlamentares - nem mesmo de parlamento. De fato, em algumas das primeiras disputas na Câmara durante a Regência, estava claro que a função básica do partido político, particularmente a idéia de um partido de oposição, era intensamente debatida, e não apenas porque a ameaça de conflito era bastante real. Na opinião de alguns, o partido podia ter ou não autoridade legítima, cujo papel repressivo seria explícito. ${ }^{2}$ Essa noção não foi algo que desapareceu rapidamente no desenvolvimento dos partidos; na verdade, foi um importante argumento do Partido da Ordem, no final da década de 1840, de que o partido opositor, os luzias, era essencialmente ilegítimo, pois tinha proposto a reforma da Constituição e pegado em armas contra o Estado em 1842. ${ }^{3}$

Outro aspecto dos partidos naquela época diz respeito à sua organização, que era muito diferente do que normalmente se entende por um partido político nos dias de hoje. Um partido era claramente caracterizado por um senso de liderança altamente pessoal, pela ausência de uma agenda ideológica e geral ou de publicações e de manifestos, por sua visivel relação com redes de parentesco e por seus apelos a interesses especificos (classe, nacionalidade etc.).

Parte disso é evidente desde o começo, como no modo com que a Assembléia Constituinte de 1823 se dividiu em duas grandes facções, ambas conduzidas por oradores e apelando para alianças de classe e de nacionalidade. Muitos dos estadistas que representavam seu eleitorado local e regional em 1823 retornaram ao Rio na primeira e na segunda legislaturas (respectivamente, 1826-30 e 1831-34) e, novamente, compuseram o que ficou conhecido como "oposição liberal". Esse não é um período sobre o qual eu possa alegar algum conhecimento especial, mas, em minha opinião, ali se estabeleceu o cenário partidário do início da Regência, em que a Câmara estava dividida em duas facções. Uma era a que apoiava o imperador e alinhava-se tanto à oligarquia luso-brasileira, que dominava as nomeações para o governo e as principais famílias de negociantes e fazendeiros da Corte e da baixada fluminense, quanto a seus congêneres nas províncias do nordeste. A outra era a facção que estava alinhada às oligarquias regionais excluidas das nomeações e benefícios do Estado, bem como à população urbana intermediária, que desejava uma forma de governo mais representativa. Esta facção, a da aliança entre oligarquias excluídas e elementos urbanos subalternos, era a base da "oposição liberal", associada principalmente a homens como Bernardo Pereira de Vasconcelos, Evaristo Ferreira da Veiga e Diogo Antônio Feijó. ${ }^{4}$

Em um primeiro esforço de discutir modelos ou locais de organização, três pareceram se destacar na prática histórica do início da Regência: maçonaria, sociedades e seus respectivos periódicos, e oradores que falavam das oligarquias regionais e para elas. $5 \mathrm{Em}$ minha pesquisa sobre a história política do periodo, a maçonaria pareceu relativamente secundária, uma organização de apoio, em comparação com as sociedades. Por fim, o terceiro modelo, de oradores falando das oligarquias regionais e para elas, pareceu ser primordial e fundamental para a compreensão da origem dos partidos. Os oradores, necessariamente ligados às oligarquias por sangue, matrimônio ou 
Ver NEEDELL, Jeffrey D. Party Formation and State-Making: The Conservative Party and the Reconstruction of the Brazilian State, 1831-1840. Hispanic American Historical Review, vol.81, n.2, p.259-308, mai./2001, especialmente, p.261-265 e p.289-298, e a análise mais elaborada em NEEDELL, Jeffrey D. The Party of Order: The Conservatives, the State, and Slavery in the Brazilian Monarchy, 1831-1871. Stanford: Stanford University, 2006, caps.1-2, passim.

7

Os principais eventos são refletidos nos debates da Câmara e nos periódicos ou memórias da época; ver, por exemplo, Annaes do parlamento brazileiro: Camara dos Srs. Deputados. (1876-1884). T.II. Rio de Janeiro: Hypolito José Pinto, et al., 30-31 Julho, 1831, p.129-38; Aurora Fluminense, 3 de agosto de 1832, passim, 21 de setembro de 1832, passim; SILVA, João Manuel Pereira da. Historia do Brazil: durante a menoridade de D. Pedro II, 1831a 1840. $2^{a}$ ed. Rio de Janeiro: Garnier [c.1878], p.99-105, p.112, p.124-130, p.133-134, p.140-142, p.151-

152, p.153-154; em relação ao contexto e debate das reformas liberais, assim como às ameaças de restauracionismo, que ensejaram o Ato Adicional, ver: OTTONI, Theophilo Benedicto. Circular dedicado aos Srs. Electores pela Provincia de Minas Gerais. 2ed. São Paulo: Irmãos Ferrez, 1930 [1860]. p.40; OTONI, Cristiano Benedito. Autobiografia. Brasilia: Universidade de Brasilia, 1983 [1908]. p.34-35, p.37-38; Visconde do Uruguay. Estudos practicos sobre a administração das provincias no Brazil. 2 volumes. Rio de Janeiro: 1865, vol.1, p.xiixviii; SILVA, João Manuel Pereira da. Historia do Brazil: durante a menoridade de D. Pedro II, 1831 a 1840. $2^{\mathrm{a}}$ ed. Rio de Janeiro: Garnier [c.1878], p.23-27, p.43-44, p.106-110, p.150-158; Annaes do parlamento brazileiro: Camara dos Srs. Deputados. (1876-1884). T.I. Rio de Janeiro: Hypolito José Pinto, et al., 1831, p.70-87, p.220-224. Ibidem, t.2, p.133142; Ibidem, t.l 1834, p.9-34. Ibidem, t.2, 29 de julho, p.161-165.

8

Ver, por exemplo, TORRES, Rodrigues. Annaes do parlamento brazileiro: Camara dos Srs. Deputados. (1876-1884). T.II. Rio de Janeiro: Hypolito José Pinto, et al., 1834, p.97, 16 de julho. convicção, articularam a direção política; as oligarquias proporcionavam as bases para os votos. ${ }^{6}$ Como veremos, os oradores cujos discursos tinham por objeto e destinatário grupos socioeconômicos intermediários ou camadas pobres urbanas não eram capazes de sustentar a força política por si mesmos; os elementos que eles representavam não podiam fornecer o suficiente de riqueza, respeito, influência e estabilidade. Assim, tais oradores, os exaltados - ativistas políticos mais radicais tiveram que se aliar às oligarquias para construir uma força suficiente para sobreviver (muito menos do que qualquer esperança de sucesso político). 0 que eles ofereciam em troca de tal apoio entrava em jogo em momentos de crise política. Era então que esses oradores e grupos poderiam ser importantes na aliança com mais facções oligárquicas, e até mesmo vencer. Voltemos à história para dar especificidade e vida a muitas dessas generalidades.

\section{Origens do partido majoritário ou Partido da Reação, 1820-1837}

A maior parte da historiografia concorda que o primeiro partido duradouro foi aquele formado pela maioria na Câmara em 1837, que veio a ser chamado de Partido Conservador. Fontes publicadas na época e a historiografia mais antiga também deixam claro que esse partido derivou dos moderados, liberais moderados que dominavam a "oposição liberal" e a administração no início da Regência após a ruptura com seus aliados mais radicais, os exaltados, que estavam ligados à oposição mais radical, e mesmo à ala republicana, da década de 1820. No meu trabalho, recuperei a história dessa transição, na qual os liberais moderados, que já haviam expulsado os exaltados, dividiram-se em torno da questão sobre a intensidade da reforma constitucional liberal, enquanto se devia manter o poder do Estado particularmente contra a ameaça imposta pelos caramurus - o partido restauracionista que ainda pretendia trazer de volta o primeiro imperador. Em resumo, uma tentativa inicial (1832) de empreender reforma imediata e radical por meio de violência, dividiu os moderados mais reformistas, sob Feijó, dos moderados mais cautelosos, liderados por Honório Hermeto Carneiro Leão, futuro Marquês do Paraná, que ficou impressionado com a ameaça de uma radicalização rápida e violenta contra um estado forte e constitucional. Os homens que se uniram a ele formaram um grupo grande o suficiente para malograr a tentativa, mas não estável o bastante para dominar a Câmara e, por sua vez, o Estado. Ao invés disso, seguiram-se cinco anos de polêmicos debates, nos quais os reformistas moderados, mal tendo aprovado o Ato Adicional de 1834, tiveram, então, que enfrentar tanto a crítica da oposição como as ameaças à ordem social e à integridade nacional subseqüentes à aprovação do Ato. Pesquisadores do periodo se lembrarão das diversas revoltas urbanas e rurais de meados da década de 1830, em especial a tentativa de secessão no sul e a revolta social de contornos raciais na Amazônia. ${ }^{7}$

No triunfo dos reformistas de 1834 , vemos também os primeiros passos em direção à organização de um partido que reagiu às violentas ameaças à ordem estabelecida associadas ao Ato Adicional e aos reformistas que o promoveram. Alguns desses passos foram dados durante os próprios debates, em que estadistas moderados defendiam a necessidade de um estado forte e a preservação da monarquia. Joaquim José Rodrigues Torres foi particularmente incisivo na defesa de ambos. ${ }^{8}$ 
No original, "reactionary" . Como explica na réplica aos comentadores deste texto (publicada a seguir), o autor emprega o termo "reactionary" como o mais próximo correlato disponivel, em inglês, dos termos "regresso" ou "regressista". Não haveria razão, portanto, para traduzir suas ocorrências como "reacionário", na versão em português (N.T.).

\section{0}

Ver H.H. Carneiro Leão a José da Costa Carvalho, Rio, 9 de outubro de 1834. Instituto Histórico e Geográfico Brasileiro [daqui em diante IHGB], lata 219, doc.49, ns. 1, 2; Aurora Fluminense, 22 de junho de 1835, 3596; 1 de julho de 1835, 3960; os dados eleitorais estão em Annaes do parlamento brazileiro: Camara dos Srs. Deputados. (18761884). T.Il. Rio de Janeiro: Hypolito José Pinto, et al., 1835, p.368-369.

11

Paulino. Annaes do parlamento brazileiro: Camara dos Srs. Deputados. (1876-1884). T.l. Rio de Janeiro: Hypolito José Pinto, et al., 1841, p.556, 15 de junho.
Menos retóricos, outros passos foram dados no curso da eleição, naquele ano, para a nova e reformada regência. 0 Ato Adicional tinha acabado com os três regentes da Constituição de 1824 e convocara, em seu lugar, a eleição direta de um único regente, um tipo de presidente à maneira dos Estados Unidos. Honório, figura-chave entre os moderados opositores à ala reformista, tentou costurar uma alternativa ao candidato reformista, Feijó. Mas atrairia os votos necessários apenas um estadista cujo apelo reunisse os moderados mais cautelosos e os antigos seguidores do primeiro imperador, bem como unificasse as oligarquias do Rio de Janeiro, Minas, São Paulo, Bahia e Pernambuco. Honório apelou para o medo e para a necessidade de uma liderança estável e respeitável era mais um apelo anti-Feijó e anti-radical que qualquer outra coisa. Faltava-Ihe um apelo ideológico positivo e unificador e, mais importante, faltava-Ihe um líder político destacado cujo prestígio bastasse para vencer. Dessa maneira, o intento fracassou; embora somasse mais votos que os apoiadores de Feijó, oposição regressista ${ }^{9}$ os dividiu entre vários candidatos regionais, e Feijó venceu. ${ }^{10}$

Nos dois anos seguintes, contudo, um núcleo organizado e estável de um partido de reação se desenvolveu precisamente a partir de uma daquelas regiões, a principal delas formada pela Corte, pela provincia do Rio de Janeiro e por grupos do sul de Minas a elas associados. Aqui, reconstrui a história a partir de análises cuidadosas de carreiras, atentando para dados cronológicos. Em essência, moderados importantes, ligados por um misto de reação ideológica, nomeações do governo, representação parlamentar e oligarquias regionais, uniram-se nas próprias instituições de governo imperiais e provinciais e nas legislaturas estabelecidas pelos reformistas de Feijó, começando a organizar projetos legislativos e eleições partidárias em oposição a Feijó e ao Ato Adicional. Os espaços para essa organização compreendiam a magistratura, a Assembléia Legislativa do Rio de Janeiro, a presidência dessa província e a Câmara. Seus principais líderes articularam Vasconcelos e Honório a um importante grupo fluminense liderado por Rodrigues Torres, quem havia formado, por indicação, eleição e casamento, um grupo de homens reconfortados na assembléia provincial e diretamente conectados a uma extensa rede de famílias de plantadores de cana-de-açúcar da baixada fluminense. Paulino José Soares de Sousa foi um ator importante nesse processo e lembraria mais tarde, em 1841, que o movimento para constituir um novo partido finalmente ocorreu em 1837 como algo realizado por seus "amigos, e pelo círculo em que vivi"."11

Paulino, assim, referia-se precisamente às redes ideológicas que mencionei acima. Indicado para a magistratura em 1832, sob a proteção de Feijó e do então regente (José da Costa Carvalho, futuro Marquês de Monte Alegre), Paulino havia rapidamente se mostrado competente. Honório o introduzira na magistratura da Corte em 1833, onde impressionou Rodrigues Torres, concunhado de Bernardo Belisário Soares de Sousa, seu tio. 0 próprio Paulino se casaria com uma irmã das esposas de Torres e de Belisário naquele mesmo ano, atraindo assim o apoio e o prestígio dos Álvares de Azevedo, a influente e ramificada família de proprietários a que me referi acima. Quando a facção de Feijó buscou assegurar seu apoio por meio de uma nomeação a ministro, ele a recusou, optando, ao invés disso, por ingressar na Assembléia do Rio de Janeiro. 
12

Sobre as idéias de Paulino e suas conexões politicas, ver, por exemplo, Annaes do parlamento brazileiro: Camara dos Srs. Deputados. (1876-1884). T.II. Rio de Janeiro: Hypolito José Pinto, et al., 1837, p.68-73, 10 de julho, e Paulino José Soares de Souza a Francisco Peixoto de Lacerda Verneck, s.p., 22 de setembro de 1836. AN, AP29, PY caixa 379, pacote 1, doc.183; Paulino José Soares de Souza a Francisco Peixoto de Lacerda Verneck, Niterói, 19 de fevereiro de 1837. Ibidem, doc.233; Paulino José Soares de Souza a Francisco Peixoto de Lacerda Verneck, Niterói, 15 de março de 1837. Ibidem, doc.234; Paulino José Soares de Souza a Francisco Peixoto de Lacerda Verneck, Santo Domingos, 29 de setembro de 1837. Ibidem, doc.235.2; Paulino José Soares de Souza a Francisco Peixoto de Lacerda Verneck, Niterói, 9 de janeiro de 1838. Ibidem, doc.235.3; Paulino José Soares de Souza a Francisco Peixoto de Lacerda Verneck, Niterói, 25 de março de 1839. Ibidem, doc. 235.4.
Ali Paulino construiu suas conexões políticas, sucedeu Rodrigues Torres como presidente de província e começou a estabelecer a rede de apoio provincial. É fundamental observar que Paulino, aparentemente, conseguiu isso articulando desde as terras canavieiras da baixada até os cafeicultores do Vale do Paraiba, os quais estavam em meio à expansão inicial do café, que passava, então, a suplantar o açúcar nas exportações fluminenses (e brasileiras). Embora o peso político dos cafeicultores ainda estivesse em formação, se comparado à estabelecida e bem entrosada baixada, esses plantadores de café seriam paulatinamente essenciais para 0 desenvolvimento do partido. No entanto, Paulino não era apenas um juiz bem sucedido e um líder partidário; era ambos graças a uma combinação de tato pessoal com acuidade intelectual e judiciária. Uma mostra disso foi o fato de ter sido rapidamente arregimentado para trabalhar com os homens importantes da Reação na crescente crítica ao Ato Adicional, primeiro na assembléia, com José Clemente Pereira, e então, depois de sua eleição para a Câmara, em 1836, com Vasconcelos. ${ }^{12}$

0 núcleo fluminense com o qual Paulino foi rapidamente associado era a fundação do partido. No entanto, como Honório havia feito, seus caciques lograram aproximar-se de caciques das oligarquias rurais e comerciais das provincias do Nordeste. Até 1837, os caciques do Nordeste já haviam sido recrutados: Miguel Calmon Du Pin e Almeida e Francisco Gonçalves Martins, da Bahia; Antonio Peregrino Maciel Monteiro e Pedro de Araújo e Lima, de Pernambuco. Formidáveis oradores, representativos ou exemplares das grandes oligarquias rurais da antiga região açucareira, todos serviriam para legitimar o novo partido em suas regiões e conduzi-lo à vitória. Não era apenas questão de visões em comum - havia o fato de que tais caciques possuiam interesses comuns com o eixo fluminense-mineiro em relação à estabilidade política e social para a ordem estabelecida. Era uma questão muito prática também. Como Honório demonstrara, os membros da reação, no norte e no sul, reconheceram a evidente necessidade politica de contar com deputados provinciais da Bahia e de Pernambuco, se quisessem somar maioria dos votos na Câmara. Eles falharam em encontrar um líder político comum para disputar a eleição com Feijó; agora, para se opor a ele, precisavam achar, ao menos, uma posição comum em torno da qual se uniriam nos debates. Voltemo-nos aos interesses e idéias centrais dessa posição.

Se as idéias que Honório havia explicitado em correspondência e em seu discurso de 1832 tinham algo em comum, era o medo, medo de mudança radical, rápida e irresponsável, a qual ele e seus aliados associaram a Feijó e aos reformistas e radicais que o apoiavam e encorajavam reformas políticas. Os debates do Ato Adicional também suscitaram questionamentos fundamentais sobre a própria concepção de monarquia, bem como da natureza do papel do monarca e do grau de descentralização apropriado à administração nacional. Tais debates dificilmente seriam mero exercício de imaginação, especialmente no primeiro lustro da década de 1830, quando houve tentativas de golpes, secessão provincial no Rio Grande do Sul, revoltas urbanas e guerrillas rurais duradouras nos sertões do Nordeste (e, após 1835, adentrando a Amazônia). Pelo contrário, esses eventos tornaram bem palpável a ameaça à ordem social e à integridade nacional. Em 1834, vários deputados votaram a favor do Ato Adicional, sobretudo por temer a restauração 
13

Sobre a visão de Feijó acerca da situação, ver: Feijó para Antonio Pedro da Costa Ferreira, Rio de Janeiro, 5 de Janeiro de 1836. Biblioteca Nacional Seção Manuscrito, Coleção Tobias Monteiro [daqui em diante, BN, SM, CTB], P110. Sobre a visão geral na Câmara, ver os debates e memórias citadas acima em n.7 para as reformas e seu contexto.

\section{4}

Sobre o contrabando de escravos e suas consequências, ver NEEDELL, Jeffrey D. Abolition of the Brazilian Slave Trade in 1850: Historiography, Slave Agency, and Statesmanship. Journal of Latin American Studies, vol.33, n.4, Nov./2001, p.689711; especialmente, p.682-687, p.688-696. A pressão de José Clemente para legalizar novamente o tráfico de escravos africanos se deu por meio da Assembléia Provincial do Rio de Janeiro, ver Jornal do Commercio, 2 de dezembro de 1837, 1; Vasconcelos, pela Câmara, ver, Annaes do parlamento brazileiro: Camara dos Srs. Deputados. (1876-1884). T.II. Rio de Janeiro: Hypolito José Pinto, et al., 1835, p.109, 24 de julho.

\section{5}

0 liberalismo dos homens mais velhos está bem colocado nos debates acima citados e na historiografia. 0 de Paulino é visivel em: Visconde do Uruguay. Ensaio sobre o direito administrativo. 2 volumes. Rio de Janeiro: Typ. Nacional, 1862, e Idem. Estudos practicos sobre a administração das provincias no Brazil. 2 volumes. Rio de Janeiro: 1865. Para o de Eusébio, ver seus discursos contra as reformas eleitorais de Honório na administração da Conciliação, citada abaixo. Espero publicar algo sobre o papel dos Conservadores no liberalismo brasileiro do século XIX em "Variations on a Theme: Liberalism's Vagaries Under the Brazilian Monarchy". In: JAKSIC, Iván and CARBÓ, Eduardo Posada (eds). Liberalism in Nineteenth-Century Latin America, no prelo.

\section{6}

Evaristo deve ter usado "Regresso" primeiramente para caluniar Vasconcelos; ver Aurora Fluminense, 1 de julho de 1835, 3960; 4 de novembro de 1835, 40076; cf. T. Ottoni. Jornal do Commercio, 22 de maio de 1838,2 . Ver a resposta de Vasconcelos em Sete d'Abril, 19 de maio de 1838, 1; 16 de maio de 1838, 1-2; 25 de maio de 1838, 102; Jornal do Commercio, 21 de maio de 1838, 4; Vasconcelos. Annaes do parlamento brazileiro: Camara dos Srs. Deputados. (1876-1884). T.II. Rio de Janeiro: Hypolito José Pinto, et al., 1837, p.293-294, 9 de agosto. Ibidem. T.1. 1838, p.106, 12 de maio; p.301, 7 de junho. de Pedro I e desejar enfraquecer a monarquia e o estado imperial como forma de romper o evidente absolutismo de Pedro. Entretanto, depois da votação, chegaram notícias anunciando que o antigo imperador havia morrido naquele ano (1834). Agora, o potencial excesso de poder na Corte parecia menos assustador que a realidade dos muitos levantes sociais e políticos nas províncias e nas cidades portuárias. ${ }^{13}$ Além disso, deve-se recordar que o tráfico de escravos africanos, depois de um periodo de breve declínio após ter sido considerado ilegal em 1831, estava então crescendo rapidamente em volume para manter a progressiva produção de açúcar e o boom do café. A necessidade de um estado forte, para manter a ordem social baseada na escravidão africana em expansão e para garantir esse investimento constante e essa aspiração econômica, deve ter pesado bastante nos cálculos dos fazendeiros e negociantes que dominavam o interior e muitos dos portos. De fato, tanto Vasconcelos (em 1835) como José Clemente (em 1837) convocaram a refutação dos tratados e da legislação que deveria encerrar o tráfico africano em 1831.14

Se temores pela ordem estabelecida e pela direção da sociedade foram fundamentais para a reação de muitos deputados, é importante reconhecer também que, em suas próprias histórias e conjecturas, muitos deles, particularmente os caciques que lideravam o novo partido, permaneceram liberais, com um compromisso profundo com o equilibrio de poder entre o monarca e o parlamento que representava seus interesses. Vasconcelos, Rodrigues Torres e Honório foram bastiões da "oposição liberal" do Primeiro Reinado e figuras centrais nas primeiras administrações moderadas da Regência. Partidários mais jovens, tais como Paulino e Eusébio, nenhum dos quais tinha idade suficiente para ter se envolvido com o Primeiro Reinado, não se engajaram na defesa de um governo representativo contra o primeiro monarca. Entretanto, eles também dariam indícios de uma forte crença no equilíbrio de poder, no papel representativo do governo de gabinete e em outros principios do liberalismo. ${ }^{15}$ Embora esses homens fossem estigmatizados de regressistas por seus antigos aliados, a contradição é menor do que parece. Eles permaneceram firmes defensores do governo parlamentar, representativo e constitucional, como sempre o haviam sido. Simplesmente passaram a se preocupar com a segurança do Estado e da sociedade que dominavam ao lado das oligarquias que representavam. ${ }^{16}$ Voltaram-se, assim, para a monarquia e para o Estado mais centralizado e autoritário que ela significava. Embora tal mistura, monarquismo liberal, pareça um oximoro para muitos hoje em dia, no contexto hemisférico da época, em particular, as referências políticas pertinentes a muitos envolvidos no debate eram européias, especialmente teorias francesas e práticas parlamentares inglesas. Tanto na França como na Inglaterra, a monarquia constitucional era uma solução comum para o problema imposto pelo desejo de uma política estável e progressiva na esteira da Revolução Francesa e no contexto dos movimentos revolucionários liberais do início do século XIX.

Isso pode ser observado nos debates parlamentares de meados da década de 1830. Enquanto os liberais mais reformistas tendessem a se espelhar nos Estados Unidos, a liderança da nova maioria preferia aludir a Guizot e aos doctrinaires da Monarquia de Julho francesa (1830-1848). Vasconcelos, o mais teórico dos líderes do novo partido, foi explícito em sua admiração por Guizot e em sua crítica ao modelo dos Estados 
17

Vasconcelos. Annaes do parlamento brazileiro: Camara dos Srs. Deputados. (1876-1884). T.I. Rio de Janeiro: Hypolito José Pinto, et al., 1834, p.170, 23 de junho; p.199, 26 de junho; Ibidem, t.2, p.10-12, 1 de julho; Ibidem, p.32-33, 4 de julho; Ibidem, p.41-44, 7 de julho; Ibidem, p.72-73, 11 de julho; Ibidem, p.77, 12 de julho; Ibidem, p.99-100, 16 de julho; Ibidem, p.114, 18 de julho; Ibidem, t.I, 1837, p.191, 5 de junho; Limpo de Abreu and Vasconcellos. Ibidem, t.II, p.128-129, 17 de julho; Vasconcellos. Ibidem, p.287, 7 de agosto; Ibidem, p.293, 9 de agosto; Ibidem, t.I, 1838, p.300, 7 de junho. Visconde do Uruguay. Ensaio sobre o direito administrativo. 2 vols. Rio de Janeiro: Typ. Nacional, 1862, e Visconde do Uruguay. Estudos practicos sobre a administração das provincias no Brazil. 2 volumes. Rio de Janeiro: 1865

\section{8}

Sobre o partido e seus nomes, ver as mudanças na prática nesses exemplos da liderança pública do partido (Pereira da Silva foi um distinto militante do partido desde o princípio e durante sua impressionante história; Justiniano José da Rocha, cuja lealdade também data da década de 1830, foi o mais distinto jornalista do partido): SILVA, João Manoel Pereira da. Memorias do meu tempo. 2 volumes. Rio de Janeiro: Garnier, 1895-1896, vol.1, p.12; p.6-27. Honório. Jornal do Commercio, 7 de março de 1843, 1 e 14 de maio de 1844, 1; [Justiniano José da Rocha]. 0 Brasil, 16 de junho de 1840; 20 de junho de 1840, 4; 28 de setembro de 1844, 1; 23 de novembro de 1847, 4; Paulino. Annaes do parlamento brazileiro: Camara dos Srs. Deputados. (1876-1884). T.II. Rio de Janeiro: Hypolito José Pinto, et al., 1850, p.200, 15 de julho; Eusébio. Jornal do Commercio, 19 de julho de 1855, 4.

\section{9}

Constituição politica do Imperio de Brazil. Rio de Janeiro: Silva Porto, 1824, Cap.VI, Arts.9097; sobre a influência eleitoral, ver, por exemplo, Aurora Fluminense, 1 de abril de 1833, 3206; 9 de março 3199-3200, Paulino José Soares de Souza a Francisco Peixoto de Lacerda Verneck. Santo Domingos, 29 de setembro de 1837, AN, AP29, YP, caixa 379, pacote 1, doc.235.2; Paulino José Soares de Souza a Francisco Peixoto de Lacerda Verneck, Niterói, 25 de março de 1838. Ibidem, doc.235.4; H.H. Carneiro Leão a José da Costa Carvalho, Rio de Janeiro, 9 de outubro de 1834, IHGB, lata 219, doc.49, ns.1-3. Cf. as pesquisas sobre comportamento eleitoral em: BIEBER, Judy. Power, Patronage, and Political Violence: State Building on a Brazilian Frontier, 1822-1889. Lincoln: Univ. of Nebraska, 1999, cap.3 e GRAHAM, Richard. Patronage and Politics in Nineteenth-Century Brazil. Stanford: Stanford Univ., 1990, cap.4.
Unidos. Enquanto considerava inapropriadas, para a realidade brasileira, as soluções norte-americanas de governo, julgou totalmente aplicáveis o pensamento e o exemplo de Guizot. Assim, encontramos um argumento de excepcionalidade sobre o Brasil, mas que adquiriu força pela adaptação de certo modelo e de certa ideologia estrangeira. A busca de um equilibrio nos poderes e no governo, a adoção do parlamento como espaço importante para encontrar soluções por meio do debate bem preparado, o papel central da monarquia como garantidora de uma ordem estável, a aversão ao extremismo, fosse democracia ou absolutismo; tudo isso é central no pensamento e na prática política de Guizot e se tornou essencial na articulação, feita por Vasconcelos, das idéias e das práticas do novo partido. Embora seja lugar-comum dizer que a Monarquia de Julho e o Ecletismo tenham sido influências importantes para a Monarquia, os debates decisivos de 1837-1841, anos cruciais do Regresso, explicitam essa influência; assim como o faz a obra de Paulino, herdeiro intelectual de Vasconcelos, em muitos dos pressupostos de seus trabalhos sobre administração liberal publicados na década de $1860 .{ }^{17}$

Com efeito, o partido que formou a maioria em 1837, embora referido sem um nome próprio (as referências eram da própria realidade política - as pessoas falavam do partido da maioria, o partido do gabinete), era, em boa parte, um partido proveniente dos traumas dos moderados durante meados da Regência (1832-1837). Era um partido organizado em torno de desafios políticos do momento, criado por certos estadistas que, por volta de 1835, começaram a agir contra um conjunto comum de ameaças. Eles é que atingiram envergadura desde o parlamento até as províncias, inicialmente encontrando seu núcleo na Corte e seu interior, e depois fazendo alianças com homens de perfil semelhante e de eleitorado similar nas maiores províncias do Nordeste. Essas alianças deram-Ihes a maioria; já seu entendimento da necessidade de uma política liberal representativa e equilibrada, garantida por um Estado forte e centralizado, Ihes forneceu a perspectiva ideológica. Tudo isso já estava pronto em 1837. Uma cuidadosa análise dos indivíduos e das publicações da época esclarece que foram essas as origens do partido que conhecemos como Conservador, um nome que adotaram apenas na década de 1850, evitando o antigo e mais comum Partido da Ordem, ou o mais coloquial saquaremas. ${ }^{18}$ Quais foram, então, as origens do partido que se opunha a eles?

\section{Origens do Partido da Oposição, 1831-1840}

Dentro da grande massa daqueles qualificados para votar, um número muito menor era qualificado para ser eleitor, e um grupo ainda menor podia candidatar-se para o cargo de deputado ou senador. Nesse sentido, a Constituição tinha reproduzido a lógica hierárquica da sociedade brasileira. Com efeito, em sua maioria, os votantes eram simplesmente a elite da massa de homens livres, na medida em que tinham um mínimo de propriedade, receita ou outro recurso à independência. Na realidade, os padrões de votação sugerem que mesmo esses homens dependiam dos "influentes" locais, figuras centrais dentre grandes proprietários de terras ou mercadores locais, aos quais os votantes se submetiam no campo e na cidade. ${ }^{19}$ Obviamente, é por isso que aqueles que votavam na esperança de romper ou modificar a ordem social, política e econômica estabelecida 
20

As idiossincrasias das origens do novo partido da oposição aparecem em Paulino José Soares de Souza a Francisco Peixoto Lacerda Verneck, Niterói, 25 de março de 1838. AN, AFW, caixa 373, pacote 1, Doc.234.4; Jornal do Commercio, 25 de maio de 1838, 2-3; 26 de agosto de 1843, 1-2; Annaes do parlamento brazileiro: Camara dos Srs. Deputados. (1876-1884). T.I. Rio de Janeiro: Hypolito José Pinto, et al., 1839, p.164, 25 de maio; p.184-186, 28 de maio; p.245, 1 de junho; Ibidem, t.1, 1840, p.580, p.584, 2 de Junho; p.598-602, 3 de Junho. eram sempre a minoria dos votantes - mesmo antes das grandes fraudes e coerções que eram empregadas com crescente aceitação e regularidade depois de 1841.

Com efeito, embora um arranjo político mais democrático pudesse ser objetivamente do interesse da maioria dos votantes, eles não votavam por isso. Aqueles que o fizeram - os exaltados ou os reformistas moderados do final da década de 1820 e da Regência - elegeram uma facção minoritária na Câmara. Para ter algum poder nos debates e nas legislaturas, tais minorias tinham que se alinhar a outros para enfrentar o partido dominante. Nos períodos de 1826-1831 e 1831-1834, era o que ocorria - os exaltados se aliavam oportunamente a outro partido de minoria para enfrentar a administração e seu partido na Câmara. 0 primeiro dos dois aliados dos exaltados ficou posteriormente conhecido como os moderados; o segundo foi citado anteriormente - os restauracionistas ou caramurus. Como ocorrera na "oposição liberal" da década de 1820, os exaltados ajudaram a formar a oposição ao partido dominante; nessa mesma época, o partido dominante era o partido do imperador; no início da década de 1830 , ele era composto por seus antigos aliados, os moderados.

Os moderados se tornaram dominantes por ter a maioria na Câmara. Como foi explicado, entretanto, a unidade dos moderados rompeu-se no periodo de 1832 a 1834 e se dissolveu totalmente após o Ato Adicional de 1834 e a morte do primeiro imperador, Pedro, Duque de Bragança. Feijó, um dos chefes tradicionais da esquerda moderada, simplesmente manteve-se como chefe dessa ala, enquanto a direita moderada deixou o partido, em reação ao Ato Adicional e à liderança de Feijó, e, recrutando a maioria dos caramurus, reagruparam-se no partido da reação que compôs a maioria da Câmara em 1837. Se a ala da direita, sob moderados como Vasconcelos, Rodrigues Torres e Honório, conquistou o apoio dos caramurus e de outros indivíduos mais conservadores das oligarquias provinciais, os negociantes e a burocracia da Coroa, o partido de Feijó também recebeu novas adesões. 0 reformista ganhou o apoio dos exaltados, como Teófilo Benedito Otoni. Mais interessante, em 1837, com a ascensão da maioria regressista, esse novo partido minoritário reformista-radical aliou-se com aqueles elementos da antiga oposição que, por razões pessoais ou provinciais, não poderiam apoiar o Regresso: homens como Francisco Gê Acaiaba de Montezuma (futuro Visconde de Jequitinhonha), Antônio Paulino Limpo de Abreu (futuro Visconde de Abaeté), Aureliano de Sousa e Oliveira Coutinho (futuro Marquês de Sapucai), os dois Andradas restantes (Antônio Carlos e Martim Francisco) e Antônio Francisco de Paula e Holanda Cavalcanti de Albuquerque (futuro Visconde de Albuquerque). ${ }^{20}$ Como havia acontecido no Primeiro Reinado e no início da Regência, essa era uma aliança de ocasião, feita para fortalecer a oposição ao partido dominante. 0 fato de não haver ideologia única e absoluta, de forma que reunisse tais frações, estava inteiramente dentro dessa tradição. 0 objetivo não era avançar em direção a uma nova perspectiva: o objetivo era evitar a derrota na Câmara e atrasar a aprovação da legislação da maioria e o aumento do poder. Assim, contemporâneos se referiam ao partido como o partido da minoria ou o partido da oposição. 
Às vezes, as contradições políticas ou ideológicas podiam ser interessantes. Os Andradas e Montezuma, por exemplo, opuseram-se ao primeiro imperador vez ou outra. Entretanto, na Abdicação (1831), reconciliaram-se com Pedro I; da mesma maneira que muitos outros, tais como Aureliano ou José Clemente, perderam espaço com a queda do imperador. Enquanto homens como Aureliano e José Clemente aderiram aos moderados ou deixaram a participação política ativa por questões particulares, os Andradas, desejando disputar a primazia com os moderados, buscaram derrubar o regime por meio de organização partidária ou da violência. Em 1837, enquanto o sucesso de Aureliano entre os moderados o havia elevado ao primeiro escalão, e José Clemente e seu genro, Eusébio de Queiros Coutinho Matoso da Câmara, juntaram-se com os regressistas (uma decisão coerente com seu serviço à Coroa, seus interesses econômicos e as dificuldades de José Clemente com os exaltados no passado), os Andradas simplesmente mantiveram-se na oposição. Ainda que monarquistas, suas ambições pessoais e seus conflitos passados com homens como Vasconcelos, Honório e Rodrigues Torres tornaram a reconciliação impossível. Ao contrário, eles continuaram a contestar o poder do Estado, aliados novamente aos exaltados; mas agora, como estes, em uma liga formada por antigos inimigos moderados do grupo de Feijó e por outros do partido de oposição, faut de mieux.

Albuquerque, uma grande figura na elite monarquista rural de Pernambuco, opusera-se à centralização do primeiro imperador, atuando oportunamente na "oposição liberal" até 1831. Então, preocupado ou com a ameaça do vínculo dos moderados com sua oposição mais liberal em Pernambuco ou com uma mudança muito reformista na Constituição (provavelmente os dois), ele foi para a oposição, aliado aos Andradas. Mais uma vez, assim como eles, Albuquerque permaneceu na oposição até 1837, agora se opondo à maioria regressista, particularmente preocupado com o compromisso desse grupo com um Estado forte e centralizado, o que era antagônico a seus interesses provinciais. Surge, então, a curiosa situação de um patriarca proprietário de terras, que se colocava desesperadamente contra os exaltados em Pernambuco, mas se aliava a reformistas e exaltados no Rio, com o objetivo de fazer uma oposição efetiva ao novo partido majoritário.

Com efeito, é apenas na análise das especificidades e contingências pessoais e partidárias que as aparentes contradições do novo partido de oposição fazem sentido. Embora se opusessem uns aos outros na política ou em princípios, passados ou presentes, seus líderes tinham que se aliar se quisessem ter alguma esperança de romper ou desafiar a nova maioria. Em termos da história política do regime parlamentar estabelecido na década de 1820, esse tipo de situação era totalmente tradicional. Além disso, enquanto o partido majoritário da reação de 1837 parecia ter uma coerência ideológica no que diz respeito tanto a seus líderes quanto aos interesses oligárquicos que eles representavam, sua oposição tinha, se não no mesmo grau, ao menos uma coerência ideológica e socioeconômica suficiente para chamar a atenção. Poderse-ia argumentar, ao observar a base liberal dos líderes dos dois partidos, que o liberalismo como ideologia é espaçoso como uma mansão para abrigar um grande número de variações legítimas. 0 apelo por reforma democrática, claramente o bastião da ideologia liberal, faria sentido para os grupos urbanos intermediários de que Teófilo Otoni era representante. 
0 apelo por um governo descentralizado e mais local, outro bastião da ideologia liberal, também fazia sentido para Otoni - e faria sentido para os líderes provinciais como Albuquerque. Assim, embora se possa dizer que, entre exaltados e fazendeiros provinciais como Otoni e Albuquerque, havia notáveis diferenças de formação e de atitudes na participação política, eles ainda podiam alegar semelhantes origens ideológicas liberais que os colocavam contra os regressistas - claramente mais elitistas e centralizadores do que Otoni e mais centralizadores do que Albuquerque. Resumindo, a aliança de oposição era mais que mera oposição de ocasião.

Contudo, oportunismo político ainda é importante para compreender as origens do partido em 1837-1840 e seu primeiro triunfo - o movimento da Maioridade e o golpe de 1840. De fato, esse oportunismo político (e a incoerência ideológica ligada a ele) fica evidente nesse caso. 0 movimento foi iniciado como uma conspiração no começo das sessões parlamentares de 1840 para alcançar o poder e impedir o triunfo final do Regresso. 0 partido majoritário estava na eminência de aprovar a "Interpretação do Ato Adicional" (e o fez, de fato, em maio de 1840), bem como a importantíssima reforma judicial, conhecida posteriormente por sua data de aprovação, 3 de dezembro (1841). Ambas as reformas fortaleceriam dramaticamente o Estado e promoveriam intervenções em questões de âmbito local. De fato, proveriam a monarquia do controle político direto no mais baixo e local nível da nação, o município, por meio do novo poder do gabinete de indicar oficiais da justiça. A oposição percebeu, entre outras coisas, que isso daria ao governo central um poder político sem precedentes. De fato, quem dominasse o Ministério da Justiça poderia escolher seus aliados locais para ocupar os importantes cargos locais da justiça e da polícia e, assim, moldar o processo eleitoral local. No início de 1840, esse ministério estava nas mãos de seus inimigos. A oposição, já em minoria, enfrentou a possibilidade de ser alijada do poder permanentemente e os agentes de um Estado central hostil em seus territórios urbanos e provinciais.

Apenas uma solução era visivel para a oposição: conquistar sua nomeação para o gabinete, cujas competências podia usar para fortalecer seu poder partidário e reverter sua posição minoritária, na eleição vindoura, por meio de fraude eleitoral. Entretanto, a oposição mal poderia esperar essas indicações na situação em que estava, pois o gabinete era nomeado pelo regente, que, na época, era Araújo Lima, antigo aliado dos regressistas. É verdade que ele havia rompido havia pouco tempo com os fundadores do Regresso em uma disputa interna de poder (1839). Contudo, o regente permaneceu bem mais hostil à oposição do que a seus antigos aliados. As diferenças de Araújo Lima com a liderança da maioria eram mais por primazia pessoal do que por princípios, de que partilhavam grande parte. Suas diferenças com a oposição, no entanto, eram de longa data e estavam relacionadas a questões pessoais e ideológicas. Se almejasse a nomeação para o gabinete, a oposição tinha que substituir o regente; e isso só poderia ser feito antecipando-se a maioridade do imperador para, em seguida, beneficiar-se da gratidão do monarca.

Esse enquadramento, a explicação da força motriz da conspiração e do golpe, ressalta o oportunismo e as inconsistências ideológicas da oposição. Assiste-se ao espetáculo de Otoni, o democrata admirador do republicanismo norte-americano, um homem que havia criticado o regente por beijar a mão do imperador em público, e Lima Abreu, 
21

A análise anterior acerca da oposição em relação ao movimento da Maioridade deriva, em parte, de ARARIPE, Tristão de Alencar. Noticia sobre a Maioridade. In: LEAL, Aureliano de Araújo e ARARIPE, Tristão de Alencar. 0 golpe parlamentar da Maioridade. Brasilia: Senado Federal, 1978. p.135-225; e LEAL, Aureliano. Do Ato Adicional à Maioridade (historia constitucional e politica). In: LEAL, Aureliano de Araújo e ARARIPE, Tristão de Alencar. Op.Cit., p.3-134. Ver também Annaes do parlamento brazileiro: Camara dos Srs. Deputados. (1876-1884). T.I. Rio de Janeiro: Hypolito José Pinto, et al., 1840, p.279-280, 13 de maio; p.337350, 18 de maio; p.360, 19 de maio; Paulino José Soares de Souza a Fco. Peixoto de Lacerda Verneck, Rio de Janeiro, 15 de julho de 1840. AN, AFW, P4, caixa 379, pacote 1, doc.235.5; Honorio Hermeto Carneiro Leão a Luis Alves de Lima, s.p., maio de 1840. IHGB, lata 748, Pasta 29 [1935 transcrição de um artigo sem data em 0 Jornal por Vilhaena de Moraes]. BARMAN, Roderick J. Brazil: The Forging of a Nation: 1798-1852. Stanford: Stanford Univ., 1988. p.204-209, é mais preciso sobre o contexto legislativo.

\section{2}

Sobre as mudanças de nome, ver as referências na nota 18, acima. 0 leitor deve estar ciente de que os dois principais partidos também possuiam variações provinciais, uma indicação das realidades locais e da integração partidária aos partidos nacionais, o que será discutido na parte III do presente texto.
23

Ver NEEDELL, Jeffrey D. The Party of Order: The Conservatives, the State, and Slavery in the Brazilian Monarchy, 1831-1871. Stanford: Stanford University, 2006. p.68-70; as notas decorrem de dados biográficos da época ou posteriores e de estudos importantes como o de Maciel de Carvalho e Mosher.
Aureliano e Montezuma, antigos ministros de Feijó e defensores do Ato Adicional, trabalhando em conjunto com os poderosos das províncias, como Albuquerque, e antigos restauracionistas, como os Andradas, para adiantar a maioridade do imperador por meio de mobilização popular organizada e coordenada e de manobras parlamentares semelhantes. Seu sucesso, no golpe de julho de 1840, conduziu o imperador ao trono, contrariando a Constituição e sem apoio da maioria no parlamento, e rapidamente levou à tumultuosa e problemática década de 1840 e ao Segundo Reinado. ${ }^{21}$

As contraditórias origens partidárias e ideológicas do partido oposicionista da minoria, encobertas pelo desejo de poder em 1840, seriam reveladas repetidamente na incoerência e na confusão da década seguinte. Dividido entre uma esquerda exaltado-reformista e uma direita moderada monarquista, o partido de oposição se fragmentaria em sua direção e decisões, cambaleando desde a conquista do poder em 1840 até a divisão e a queda em 1841, as revoltas provinciais em 1842, os gabinetes efêmeros e as maiorias divididas na Câmara no qüinqüênio Liberal (1844-1848), a dramática reviravolta e a última revolta provincial reprimida em 1848, quando os regressistas foram novamente chamados ao poder.

\section{Consolidação dos Partidos, Monarca e Moderação anti- partidária, 1840-1857}

As administrações regressistas de 1848 a 1853 representaram o ápice do Partido da Ordem e, até 1854, já se auto-intitulavam Conservadores. Sua oposição, o partido minoritário de oposição de 1840, era geralmente chamada de luzias na década de 1840, após sua derrota em Santa Luzia, que encerrou as revoltas de 1842. Em meados da década de 1840, os luzias também passaram a ser conhecidos como Liberais. ${ }^{22} 0$ estabelecimento dos dois principais partidos do Segundo Reinado estava, então, consolidado na Corte e em várias das províncias mais importantes entre os anos de 1837 e 1848. Não posso explicar, tendo por base minha pesquisa, como esses partidos iniciaram o processo de construção de apoio na maioria das províncias. Entretanto, parte dessa pesquisa e a publicação de alguns outros trabalhos sugerem um padrão geral plausivel para essa organização. Por exemplo, como visto acima, defendi que os dois principais partidos se desenvolveram basicamente a partir de conflitos políticos representados por certos líderes e seus seguidores na Câmara; e que esses deputados eram representantes de grupos maiores de influentes chefes no nivel local e provincial. A natureza oligárquica local e familiar desse processo na província do Rio de Janeiro pode ser observada nos vínculos demonstrados anteriormente na biografia de Paulino. No início dessa formação partidária, os grandes líderes da Câmara agiam como intelectuais orgânicos, os mais articulados, instruídos e eloqüentes membros ou representantes das elites socioeconômicas na Corte e no interior. Inferi um processo similar nas grandes cidades portuárias do Nordeste e no interior de suas respectivas províncias. ${ }^{23}$ Há também casos especificos na Bahia, Minas Gerais e Pernambuco, bem como São Paulo e Piauí, que também nos podem ser úteis, pois sugerem a possibilidade de uma natureza partidária mais geral no nivel provincial.

$\mathrm{Na}$ Bahia, por exemplo, o clássico estudo de Wanderley Pinho sobre a carreira de Cotegipe indica que a província era politicamente apartidária 
PINHO, Wanderley. Cotegipe e seu tempo: primeira phase, 1815-1867. São Paulo: Typ. Nacional, 1937. p.67, p.69-82, p.94-101, p.110, p.112, p.115-116, p.120-123, p.125, p.127, p.130-131, p.144-148, p.150, p.153, p.161-162, p.167-173; ver, também, SILVA, João Manoel Pereira da. Memorias do meu tempo. 2 Volumes. Rio de Janeiro: Garnier, 18951896, vol.1, p.122-23, p.124, p.127, p.140, para os Liberais na Bahia e as divisões entre os caciques regressistas provinciais Wanderley e Gonçalves Martins.

\section{5}

BIEBER, Judy. Power, Patronage, and Political Violence: State Building on a Brazilian Frontier, 1822-1889. Lincoln: Univ. of Nebraska, 1999, caps. $3,4,7$, passim.

\section{6}

Ver, por exemplo, SOUZA, Paulino José Soares de. Relatorio da Repartição dos Negocios de Justiça.. na sessão ordinaria de 1841, pelo respective ministro e secretario de estado [...]. Rio de Janeiro: Typ. Nacional, 1841, p.7, p.9, p.21; SOUZA, Paulino José Soares de. Op.Cit., p.3-4, p.24-26; LEÃO, Honorio Hermeto Carneiro. Relatorio da Repartição dos Negocios de Justiça... na 2a sessão da $5 a$. Legis/atura. Rio de Janeiro: J. Villeneuve, 1843. p.7. Cf. argumento excepcional de Vasconcelos para adaptar a reforma liberal às frágeis circunstâncias em seus discursos de 1834-37, citados acima, n.17 e em B.P. de Vazos a Eusebio de Queiros Couto. Matoso da Camara, [Rio], 7 de novembro de 1849. Arquivo Histórico do Museu Nacional, Coleção Eusébio de Queirós [daqui em diante, AHMN, CEO], Eqcr31. até finais da década de $1840 .{ }^{24}$ Nesse caso, os homens influentes no âmbito provincial e local preferiam manter certa independência na relação com o partido majoritário da Reação, de 1837. Embora alguns deles tenham se comprometido prontamente com o partido (Gonçalves Martins, por exemplo), outros tinham que ser cortejados, permanecendo à distância (Cotegipe, então João Maurício Wanderley, rival dos Martins, era um desses). Estes iriam, entretanto, comprometer-se com os regressistas ao longo do Qüinqüênio Liberal, já que os gabinetes liberais do periodo intervieram na província para adquirir e manter apoio. De fato, a intervenção do governo central forçou a adesão partidária local nas províncias; se os inimigos estavam com o poder no gabinete, era preciso se comprometer com a oposição a ele na expectativa de dias melhores e da virada de sorte.

Segundo o estudo de Judy Bieber, parece ter ocorrido algo semelhante no interior mineiro. ${ }^{25}$ Até a violência eleitoral e o aumento significativo da interferência do gabinete no nível local ganharem espaço ao longo dos anos quarenta, não havia ali mobilização partidária. A mobilização local e provincial para um dos grandes partidos nacionais veio, assim, como resposta à intervenção do Rio de Janeiro. Não se poderia ficar indiferente; quando os representantes locais do poder do Estado se tornaram crescentemente partidários, as oligarquias locais se alinharam a favor desses representantes e de seus respectivos partidos ou contra eles. Bieber também desenvolve uma argumentação sobre a penetração ideológica. Embora defenda que a honra pessoal e os vínculos familiares eram cruciais para a lealdade partidária, ela sugere também que as idéias eram significativas. À medida que os dois partidos se associaram aos interesses de parte das oligarquias locais ou de seus rivais, a autora propõe, ainda, a existência de identificação com suas respectivas ideologias. Em essência, a escolha pelos partidos não se dava sempre apenas em razão de rivalidades locais enraizadas e não-ideológicas.

Um apelo ideológico faz sentido. Conforme foi dito acima, as posições defendidas pelos regressistas se relacionavam, no seu nivel mais básico, ao desejo das elites que os apoiavam por uma ordem socioeconômica estável, em que um monarca forte e um Estado centralizado, se equilibrados por uma Câmara e um gabinete representativos de seus interesses, faziam sentido. Embora os grandes negociantes e fazendeiros locais talvez não fossem familiarizados com Guizot, essas questões mais amplas poderiam ser facilmente compreendidas e associadas ao partido da Reação; seus inimigos locais - pessoas não tão bem estabelecidas ou relacionadas - mover-se-iam, obviamente, na direção do partido da oposição. Entretanto, embora correligionários provinciais e líderes ou deputados nacionais do partido trabalhassem juntos para garantir o poder político no Rio de Janeiro, é provável que suas perspectivas sobre assuntos locais variassem. De fato, a possivel distância entre a visão intelectual dos líderes nacionais sobre o Estado e a perspectiva mais restrita de seus seguidores provinciais não deveria nos surpreender. Homens como Paulino, Honório e Vasconcelos compreendiam a pequena política provincial, mas inevitavelmente possuiam, com estudo, prática e experiência, uma visão mais ampla. Eles entendiam o Estado como detentor de uma "missão civilizadora" diante do atraso da sociedade nacional e estavam perfeitamente cientes da distância entre suas expectativas para o Brasil e as realidades do país. ${ }^{26}$ 
27

H.H. Carneiro Leão ao Exmo. Amo. e Snr. Queiroz, Recife, 30 de julho de 1849. IHGB, Coleção Leão Teixeira, lata 748, pasta 28, [cópia].

\section{8}

Ignacio Francisco Silveira da Mota ao IIImo. Exmo. Senr., Oeiras, 29 de janeiro 1850, marcado "particular". AN, AP07, caixa 4, pacote único, PM 1054; Ibidem, 11 de fevereiro de 1850, PM 1058; Ibidem, 28 de maio, 1850, PM 1064.

\section{9}

A ascensão e o papel de Eusébio no partido ao longo da década de 1840 e início da de 1850, como o notável "papa saquarema", aparece em Rocha a Firmino, [Rio,] 21 de março de 1844, citado em MASCARENHAS, Nelson Lage. Um jornalista do Império (Firmino Rodrigues Silva). São Paulo: Nacional, 1961. p.113; SILVA, João Manoel Pereira da. Memorias do meu tempo. 2 volumes. Rio de Janeiro: Garnier, 1895-1896, vol.1, p.123; RIBEIRO, Manuel de Queiroz Mattoso. Apontamentos sobre a vida do Conselheiro Eusébio de Queiroz. Rio de Janeiro, 1885. p.29-30, p.31-32, p.40-44; J.M Pereira. da Sa. ao Exmo. Amo. e Sr., S. Paulo, 28 de dezembro de 1848. AHMN, CEQ, Eqcr15/1. Firmino Rodrigues Silva ao Exmo. Amo. e Sr., Ouro Preto, 30 de janeiro de 1852. AHMN, CEQ, Eqcr7/2; [Eusébio] a [desconhecido], [Rio], 24 de abril de 1849. AN, caixa 9, pacote 1, PM 2082; [Eusébio] a Ribeiro, Rio, 15 de março de 1852 . AN, caixa 5, pacote 2, PM 1281. João Evangelista de Negros. Sayão Lobato ao Exmo. Amo. e Sr. Porto Alegre, 29 de dezembro de 1852. AN, AP07, caixa 4, pacote único, PM 1094; Sayão Lobato ao Exmo. Amo. e Sr. Porto Alegre, 4 de novembro de 1853. AN, PM 1095; [Eusébio] a Illmo. E Exmo. Amo. e sr., [Rio], 21 de janeiro de 1849. AN, PM 2085, [Eusébio] a Illmo. E Exmo. Amo. e sr., [Rio], 9 de março [1849]. AN, PM 2087; [Eusébio] a Illmo. E Exmo. Amo. e sr., [Rio], 20 de março de 1849. AN, PM 2088; [Eusébio] a Illmo. e Exmo. Amo. e sr., [Rio], 23 de abril de 1849. AN, PM 2089; [Eusébio] a J.E. Sayão Lobato, [Rio], 24 de abril de 1849. AN, PM 2091; [Eusébio] a Sousa Ramos, [Rio], 3 de janeiro de 1851. AN, PM 2094; [Eusébio] a Sousa Ramos, [Rio,] 3 de jan. 1851, anotado confidencial. AN, PM 2095; [Eusébio] a [desconhecido], Rio, 12 de novembro de 1851. AN, caixa 5, pacote 2, PM 1298; Wanderley ao IIImo. e Exmo. Sñr., Bahia [Salvador], 19 de novembro de 1848. AN, caixa 1, pacote 1, PM 129; Wanderley ao Illmo. e Exmo. Sñr., Bahia, 16 de novembro de 1848. AN, PM 130; Wanderley ao IIImo. e Exmo. Sñr., Bahia, 16 de dezembro de 1848. AN, PM 131.
Por vezes, a documentação mostra que esses homens sentiam-se pouco à vontade com os seguidores menos cultos de seu partido.

Em Pernambuco, por exemplo, Honório, o presidente provincial durante a Revolta Praieira (1848-1850), descreveu as oligarquias que apoiavam seu partido com certo desprezo e surpresa; para ele, tinham visão limitada e se ocupavam apenas de rivalidades provinciais, oportunismo e violência. ${ }^{27}$ Outro presidente de província, Inácio Francisco Silveira da Mota, entreviu algo semelhante nas expectativas e nas visões tanto dos saquaremas locais quanto de sua oposição no Piaui. ${ }^{28} \mathrm{Em}$ ambos os casos, os saquaremas provinciais, liderados por grandes famílias e seus aliados, esperavam que os presidentes de província de seu partido nacional usassem o cargo para defender os interesses saquaremas locais e atacar os da oposição local. Honório e Mota, ao contrário, viam sua missão como representantes de um Estado mais imparcial e civilizado. Não estou sugerindo que os líderes mais intelectuais e cosmopolitas do partido nacional estivessem desligados da realidade brutal das políticas provinciais. Quero dizer apenas que poderia haver uma diferença, compreensivel e esperável, entre os magistrados formados na Europa que representavam o partido nacional e sua base provincial, cruenta, atrelada às disputas locais.

No final das contas, entretanto, sempre é possivel dizer que, como indica a documentação, essas diferenças evaporavam perante a questão da sucessão eleitoral. Não é preciso ir além de Eusébio, que emergiu como o mais exitoso líder do partido nacional. De fato, embora fosse sutil e culto, compreendeu os brutais cálculos políticos, engajando-se neles com habilidade e sucesso, e, precisamente nos dois casos citados acima, alinhou-se à base provincial do partido, deslocando Honório e Mota, já que ambos tinham deixado claro que não pertenciam ao jogo das politicas locais provinciais. Como os oligarcas locais, Eusébio esperava que os representantes provinciais do partido cultivassem e defendessem as conexões locais, certamente no afã de assegurar o apoio local nas eleições seguintes. Ele habilmente combinou esse pragmatismo político com o mais aguçado entendimento ideológico: os saquaremas locais eram bastiões na guerra do partido pela defesa do Estado nacional contra uma oposição que ele considerava "anarquista". Na verdade, Eusébio compreendia que ideologia e pragmatismo determinavam a necessidade de atingir e manter o poder estatal. Por mais que fossem dotados de uma perspectiva paroquial, os chefes provinciais e sua capacidade de organizar o apoio local eram cruciais para esse fim. De fato, em São Paulo, era assunto de grande preocupação a ausência de líderes locais capazes de auxiliar o gabinete a organizar e sustentar alianças locais. ${ }^{29}$

Ainda que as fontes analisadas forneçam alguma idéia de como os partidos se organizaram no âmbito provincial durante a década de 1840, seria um equivoco supor que tal organização, uma vez alcançada, fosse sustentada com êxito. Quaisquer que fossem as necessidades eleitorais e ideológicas que conduziram inicialmente essa organização, seus aspectos paroquiais, contingenciais e altamente personalistas poderiam comprovar que se tratava de uma fundação instável. Há claras indicações, por exemplo, de que o mais organizado, coerente e disciplinado dos dois partidos, o Conservador, estava sujeito a vulnerabilidades regionais do início ao fim. Essa era evidentemente a fragilidade do partido no Nordeste. Assim, sua primeira vitória, em 1837, colocou um aliado 


\section{0}

Vale lembrar o leitor de que, diante da ameaça do movimento da Maioridade à sua regência e à Constituição, Araújo Lima remodelou seu gabinete para incluir caciques importantes da maioria regressista nos primeiros dias das sessões parlamentares de 1840.

\section{1}

Este ponto crucial foi inicialmente indicado por BARMAN, Roderick J. e BARMAN Jean. The Role of the Law Graduate in the Political Fate of Imperial Brazil. Journal of Interamerican Studies and World Affairs, vol.18, n.4, p.423-430, p.432447, nov./1976; e CARVALHO, José Murilo de. A construção da ordem: a elite política imperial. Rio de Janeiro: Campus, 1980, p.79, p.84.

\section{2}

Ver, por exemplo, a avaliação particular da perda de poder sobre a fidelidade política entre os Conservadores no periodo de 1854-1868 pelo conservador baiano, Eunapío Deiro a Meu caro Sr. Barão de Cotegipe, Bahia [Salvador], 15 de julho [1868], citado em PINHO, Wanderley. 0 incidente Caxias e a queda de Zacharias em 1868. In: Politica e politicos no império: contribuições documentaes. Rio de Janeiro: Nacional, 1930. p.55-128, ver p.119120.

33

É interessante observar a freqüência com que T. Otoni reconheceu explicitamente as coincidências dos dois partidos em relação ao governo representativo e à ameaça figurada pelo monarca; é interessante ver, ainda, o modo como os publicistas de ambos os partidos responderam à afirmação dos poderes do monarca ao longo da década de 1840. Ver T. Ottoni, Circular; SILVA, Firmino Rodrigues. A dissolução do Gabinete

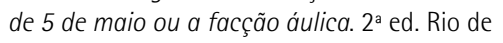
Janeiro: Francisco Rodrigues de Paiva, 1901 [1847]; HOMEM, Francisco de Salles Torres, [Timandro]. Libelo do povo. In: MAGALHÃES JÚNIOR, R. Três panfletários do Segundo Reinado. São Paulo: Nacional, 1956 [1849]. p.47-126.

\section{4}

Sobre o periodo, ver NABUCO, Joaquim. Um estadista do Império. Nabuco de Araujo: sua vida, suas opiniões, sua época. 3 Volumes. Rio de Janeiro: Garnier, s.d. [1897-1899], vol.1, p.40111; SILVA, João Manoel Pereira da. Memorias do meu tempo. 2 Volumes. Rio de Janeiro: Garnier, 1895-1896, vol.1, caps.1-10; BARMAN, Roderick J. Brazil: The Forging of a Nation, 1798-1852. Stanford: Stanford Univ., 1988. p.209-210; MOSHER, Jeffrey Carl. Pernambuco and the Construction of the Brazilian Nation-State, 18311850. Ph.D. diss., Univ. of Florida, 1996, cap. 3; CASTRO, Paulo Pereira de. A reação monárquica. In: HOLANDA, Sérgio Buarque (dir.). História geral da civilização brasileira. 3 Tomos. 5 Volumes. Tomo 2: 0 Brasil monárquico. São Paulo: DIFEL, 1967-1972, vol.2, p.509-540. Sobre o imperador, ver BARMAN, Roderick J. Citizen Emperor: Pedro II and the Making of Brazil, 1825-91. Stanford: Stanford Univ. Press, 1999, caps.2-4, passim, e LYRA, Heitor. História de Dom Pedro II: 1825-1891. como regente: Pedro de Araújo Lima, futuro Marquês de Olinda. Não se entendendo com os líderes do partido no gabinete, rompeu brevemente com eles, em 1839, e tentou governar por meio de um gabinete de conservadores de diversas origens nordestinas. ${ }^{30}$ Esse foi apenas o primeiro exemplo de uma tendência digna de nota durante o Segundo Reinado. Embora tenha sido fundamental para os êxitos iniciais dos Conservadores, como apontado anteriormente, o Nordeste foi crucial também em seus fracassos. Não estou aludindo à origem nordestina de muitos dos ministros durante o Qüinqüênio Liberal, pois eram homens ligados, afinal, à ala moderada dos Liberais. No entanto, esses liberais do Nordeste parecem partilhar uma caracteristica comum com um grupo significativo dos estadistas nordestinos do partido Conservador: uma moderação, ou mesmo um oportunismo, na história partidária que os distinguia dos radicais tanto à esquerda como à direita da política imperial - os praieiros e luzias, de um lado, e os saquaremas, de outro. Assim como os ministros que dominavam os efêmeros gabinetes de 1844 a 1848 tendiam a ser liberais moderados, leais à monarquia, tal se pode dizer também a respeito dos conservadores moderados - estadistas como Olinda, José Tomás Nabuco de Araújo e José Maria da Silva Paranhos (futuro Visconde do Rio Branco). Os estadistas nordestinos tendiam a ser mais pragmáticos em suas carreiras políticas; no início, talvez, porque o núcleo duro dos Conservadores fosse dominado por fluminenses e mineiros; posteriormente, porque a necessidade de patronagem estatal fosse se tornando cada vez mais importante (dado o lento declínio dos recursos privados e dos prospectos da elite, em razão da queda das exportações nordestinas de açúcar em meados do século). ${ }^{31}$ É digno de nota que tais homens fossem fundamentais à Conciliação e à Liga Progressista e que muitos deles deslocaram-se entre os dois grandes partidos nas décadas de 1840, 1850 e 1860.32 Nesse período, em que o imperador começou a assumir maior controle direto sobre assuntos políticos, tais homens, foram aparentemente atraidos para uma crescente moderação apartidária e para um reformismo gradual, sendo incorporados ao poder no despertar da própria direção política do imperador.

É reveladora a coincidência entre o papel crescente do imperador e essa mudança nas relações partidárias. Afinal, os dois grandes partidos da monarquia desenvolveram-se na ausência do monarca como uma fonte de poder; formaram-se logo após o colapso do Primeiro Reinado e a ascensão da Câmara como centro do poder político. A liderança ideológica dos dois partidos, embora distinta em muitos aspectos, priorizava o governo representativo e parlamentar. Os homens da Reação o destacavam como o elemento regulador de um monarca forte e como o principal aspecto legitimador do Estado centralizado; a ala radical-reformista da oposição o considerava crucial para limitar o monarca e impedir as inerentes tendências à tirania. São essas diferentes perspectivas em relação ao monarca o que mais distingue os dois partidos. Quando dominaram os conservadores, ao conquistar a maioria no parlamento, triunfou seu ponto de vista sobre o monarca. Dessa maneira, por meio das principais leis do Regresso, eles dotaram o monarca de poder e capacidade. Se tiveram quaisquer receios do uso que o monarca faria de seus recursos, eu não as encontrei - pelo menos não até 1840.33 
3 vols. São Paulo: Nacional, 1938, vol.I, caps.15. Documentos importantes sobre assuntos do período, particularmente a ilustrativa crise política associada à queda do gabinete de Honório em 1844, incluem 0 Brasil, 23 de março de 1841, 3-4; Tobias Monteiro, notas de história oral. BN SM, CTM, 116, p.9-10, p.16; Paulino, Annaes do parlamento brazileiro: Camara dos Srs. Deputados. (1876-1884). T.I. Rio de Janeiro: Hypolito José Pinto, et al., 1843, p.347-349, 23 de janeiro; Honorio Hermeto Carno. Leão ao Senhor [Dom Pedro II], [Rio, anterior a 8 de junho de 1843]. Arquivo Histórico Museu Imperial, Arquivo da Casa Imperial [daqui em diante $\mathrm{AHMI}, \mathrm{ACl}$, maço 27, doc. 970, 1-2; Honorio, Jornal do Commercio, 15 de maio de 1844, 2 e 29 de maio de 1844, suplemento, 1; D. Pedro II, Conselhos à regente. Rio de Janeiro: São José, 1958 [1871], p. 54; Honorio Hermeto Carno. Leão a Candido José de Aro. Vianna, Rio de Janeiro, 2 de fevereiro de 1844 . $\mathrm{AHMI}, \mathrm{ACl}$, maço 107, doc. 5174; correspondência citada em Lages Mascarenhas, p.111-113; Carneiro Leão, Jornal do Commercio, 14 de maio de 1844, suplemento, 1, 15 de maio de 1844, 2; Vasconcellos, Jornal do Comércio, 14 de maio de 1844, suplemento, 2.

\section{5}

A centralidade da corrupção eleitoral no Segundo Reinado é um tema político de grande relevância, pois, obviamente, ela inviabiliza qualquer alegação dos deputados e dos ministros que defendiam uma Câmara legitimamente representativa; ao contrário, eles atuavam para satisfazer o gabinete, que atuava para satisfazer o imperador. Por essa razão, ao final da década de 1840, era comumente sabido que o imperador indicava o gabinete; e este, se não desfrutasse do apoio da maioria na Câmara, pedia ao imperador para dissolver a Câmara, permitindo que eles promovessem eleições. Presumia-se que um gabinete que conduzia as eleições era um gabinete que as corrompia para recuperar o apoio da maioria. Embora nenhum partido se abstivesse dessa tradição, uma vez estabelecida, os ideólogos e líderes de ambos os partidos reconheciam seus perigos em termos de equilibrio de poderes, especificamente a capacidade de o imperador intervir em assuntos e na agenda política. Assim, tanto os Liberais como os Conservadores pregavam a reforma eleitoral, e a necessidade de recuperar a legitimidade parlamentar era uma referência comum desses esforços. Sobre pronunciamentos sobre o tema do governo de gabinete representativo, ver, por exemplo, Vasconcellos. Annaes do parlamento brazileiro: Camara dos Srs. Deputados. (1876-1884). T.II. Rio de Janeiro: Hypolito José Pinto, et al., 1837, p.287288, p.292-295, 9 de agosto; Calmon. Ibidem, p.569-570, p.572, p.573, p.576, 23 de setembro; Carneiro Leão. Ibidem, p.588-589, 27 de setembro; Vasconcellos, Jornal do Commercio, 14 de maio de 1838, 2-3; Rodrigues Torres. Annaes do parlamento brazileiro: Camara dos Srs. Deputados. (18761884). T.I. Rio de Janeiro: Hypolito José Pinto, et al., 1839, p.56-57, 20 de maio; Carneiro Leão. Ibidem, p.168, 27 de maio; Rodrigues Torres. Ibidem, p.292, 5 de junho, p.230-231, 8 de junho. Sobre os primeiros golpes em sua legitimidade, ver os documentos de 1844 e posteriores citados na n.33, bem como SILVA, Firmino Rodrigues. A dissolução do Gabinete de 5 de maio ou a facção

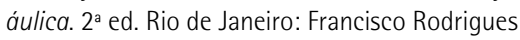
de Paiva, 1901 [1847]. T.B. Ottoni, Circular, caps. 10, 11. Sobre a reforma eleitoral, o clássico é a
Após o golpe da Maioridade de 1840, o monarca imediatamente mostrou um desejo pessoal de independência e supervisão. Ambos eram, explicitamente, atribuições suas de acordo com a Constituição de 1824, mas não um governo de gabinete representativo. Nem em 1840 nem posteriormente o imperador aceitaria ser figurativo ou agiria para fortalecer o principio de um governo de gabinete representativo formado a partir de uma maioria verdadeiramente representativa. Sua visão sobre o papel dos partidos políticos e das expectativas dos chefes dos partidos era de desconfiança. D. Pedro tinha crescido durante a Regência, quando o papel constitucional do monarca fora desafiado, em meio a uma grande insegurança pessoal e política. Na prática, ele havia se tornado órfão pelos líderes da "oposição liberal" da década de 1820 e, então, sucessivamente aterrorizado ou cortejado por muitos daqueles mesmos homens na década de 1830, uns buscando restringir seu poder, outros querendo utilizá-lo. Seria possível culpar D. Pedro por ver os estadistas fundadores dos partidos com receio e tratá-los como interesseiros, sedentos de poder? Repetidas vezes expressou, por meio de suas anotações, do uso de um favorito e de sua indisposição em ceder às pressões dos ministros, que não seria uma marionete dos velhos caciques políticos que o rodeavam. ${ }^{34}$ Seu papel representativo e imparcial era explícito na Constituição; já o papel representativo e imparcial dos chefes mal podia se ver. De fato, no início da década de 1840 , ele tinha todas as razões para associar esses homens e seus partidos à corrupção eleitoral que minava a legitimidade do governo representativo. 0 primeiro gabinete de oposição de 1840 havia flagrantemente abusado de seu poder para eleger a maioria em 1841 , e todos os gabinetes, desde então, se utilizaram da fraude eleitoral. 35

Quando recolocou os Conservadores no poder em 1848, o imperador o fez porque a fraqueza dos Liberais e a instabilidade dos radicais mostraram que o partido era um instrumento fraco. Ele compreendeu, acertadamente, que os Conservadores eram o partido mais forte, além de ser aquele mais coerentemente ligado à Constituição e a seu papel nela inscrito. Não aceitaria, entretanto, o desejo dos chefes conservadores pelo domínio partidário sobre o Estado. D. Pedro esforçou-se para restringir o partidarismo, enquanto, simultaneamente, usava a força partidária para consolidar o regime e defender seus interesses no pais e no exterior. 0 que buscou após esses líderes deixarem o ministério, em 1853, foi manter o arranjo e aumentar seu controle sobre ele. Esse é o significado essencial da Conciliação (1853-1857). Era um gabinete que, beneficiando-se da disciplina partidária dos Conservadores e do capital político de Honório, procurou desmoralizar o partidarismo ideológico e a influência eleitoral dos partidos, ao mesmo tempo em que fortalecia o papel eleitoral do gabinete, então sob a direção explícita do imperador no que diz respeito à política geral.

Essa direção frisava uma abordagem apartidária (até anti-partidária) em relação ao governo, na qual reformas eleitorais e judiciais diminuiriam o papel dos partidos no processo eleitoral, aumentando ainda mais o do gabinete, e na qual o gabinete se ocuparia do gradual desenvolvimento financeiro e infra-estrutural da nação. 0 imperador desejava que esse desenvolvimento fosse executado por homens, independentemente de seus antecedentes políticos, primordialmente leais ao Estado nacional, isto é, a ele e a sua visão sobre a "missão civilizadora" da monarquia. Tanto 
obra de SOUZA, Francisco Belisário Soares de. 0 sistema eleitoral no Império. 2a ed. Brasilia: Senado Federal, 1979 [1872]; Francisco Belisário, um saquarema, cita o Liberal CARVALHO, Antonio Alves de Sousa. 0 imperialismo e a reforma anotado por um constitucional do Maranha. Maranhao [São Luiz?], 1866, como pioneiro. Sobre o uso da reforma eleitoral como bandeira política, ver, por exemplo, Andrade Figueira, Jornal do Commercio, 4 de outubro de 1870, 2; José de Alencar, Jornal do Commercio; Pereira da Silva, Jornal do Commercio, e SILVA, João Manoel Pereira da. Memorias do meu tempo. 2 volumes. Rio de Janeiro: Garnier, 18951896, vol.2, p.124.

\section{6}

Fontes importantes sobre a Conciliação incluem "Instruções de D. Pedro II ao Visconde de Paraná: 1853", In: VIANNA, Hélio. D. Pedro I e D. Pedro II: acréscimos às suas biografias. São Paulo: Nacional, 1966. p.134-135; PINHO, Wanderley. Cotegipe e seu tempo: primeira phase, 1815-1867. São Paulo: Typ. Nacional, 1937. p.416-419; and BARMAN, Roderick, J. Citizen Emperor: Pedro II and the Making of Brazil, 1825-91. Stanford: Stanford Univ., 1999. p.162, p.164-165. A abordagem clássica é a de NABUCO, Joaquim. Um estadista do Império. Nabuco de Araujo: sua vida, suas opiniões, sua época. 3 Volumes. Rio de Janeiro: Garnier, s.d. [1897-1899], vol.1, livro segundo. Documentos sobre a resposta dos saquaremas incluem Paulino e Wanderley, citados em NABUCO, Joaquim. Op.Cit., vol.1, p.189; Franco. de Paula de Negros. Sayão Lobato to Meu estmo. Compr. e Sr., Sorocaba, 18 de março de 1854. AN, AP07, caixa 4, pacote único, PM 1035; I.F. Silveira da Mota to Exmo. Amigo e Snr., [Mato de Pipa, early 1854,]. AN, PM 1075; SILVA, João Manoel Pereira da. Op.Cit., vol.1, p.243249; Ferraz, Jornal do Commercio, 30 de junho de 1854, 2; Silveira da Mota, Jornal do Commercio, 30 de junho de 1854, supplemento, n.179; Francisco Jose Teixeira Leite, Joaquim José Teixeira Leite, Carlos Teixeira leite, João Evangelista Teixeira Leite to Illmo. Exmo. Snr., n.p., n.d. [probably Vassouras, c. maio de 1855]. AN, AP07, caixa 6 pasta 1, PM 1380; "Vassouras," Jornal do Commercio, 26 May 1855 in "Publicações a Pedido."; Sayão Lobato. Annaes do parlamento brazileiro: Camara dos Srs. Deputados. (1876-1884). T.I. Rio de Janeiro: Hypolito José Pinto, et al., 1855, p.35, 18 de maio; p.39-42, 19 de maio; J.J. da Rocha, Ibidem, p.45, 19 de maio; p.132-137, 25 de maio; Ferraz, Ibidem, p.74-81, 22 de maio; Sayão Lobato et al., Ibidem, p.89-95, 23 de maio; J. J. da Rocha, Ferraz, Ibidem, p.p.111-119, 25 de maio; J. J. da Rocha, Ibidem, p.132-137, 26 de maio; Ibidem, t.3, p.26-29, 3 de julho; Eusébio, Jornal do Commercio, 19 de julho de $1855,3-4 ; 7$ de agosto de 1855, 1 . Sobre as relações do imperador com seus ministros, ver NABUCO, Joaquim. Op.Cit., vol.2, p.94-95, p.140141; vol.3, p.6-7. Sobre o comportamento dos saquaremas em relação à posição do gabinete e ao imperador, ver, por exemplo, Visconde do Uruguay a Exmo. Ao. e Sr., Paris, 30 de maio de 1855. AHMN CEO, Eqcr84/4; Visconde do Uruguay a [Paulino José Soares de Sousa, filho], Rio, 10 de dezembro de 1856. IHGB, Arquivo Visconde do Uruguai [daqui em diante, AVU], lata 4, 2/54; SILVA, João Manoel Pereira da. Memorias do meu tempo. 2 volumes. Rio de Janeiro: Garnier, 1895-1896, vol.1, p.260; NABUCO, Joaquim. Op.Cit., vol.2, p.30 (cf. para a percepção dos saquaremas sobre o imperador em ibid, s:30, n.2). Os sentimentos de Eusébio para homens como Honório, que haviam perdido espaço para outros chefes conservadores, ou para outros ainda, tais como Olinda, Nabuco de Araújo, Caxias ou Silva Paranhos, que nunca tinham estado no núcleo duro dos saquaremas, quanto para muitos nordestinos, cada vez mais interessados na patronagem do Estado, essa administração significava uma oportunidade espetacular. Embora o imperador repetidamente tenha oferecido a mesma oportunidade para ideólogos Conservadores, como Paulino, Eusébio, Rodrigues Torres, a maioria deles não a aceitou. Opuseram-se às reformas eleitoral e judicial e à Conciliação como ataques claros ao papel do partido e do parlamento no governo representativo. Compreenderam e atacaram o potencial das reformas em fortalecer 0 poder executivo. Relutantes em aceitar pastas no gabinete, procuraram organizar e sustentar seu partido da melhor maneira que podiam, por meio de assentos no Senado ou na Câmara e do esforço em manter suas redes nos niveis locais e provinciais. Embora fossem os mais poderosos, o núcleo duro dos Conservadores, estavam atados. Eles não poderiam confrontar diretamente o imperador sem contradizer seu próprio monarquismo; assim, dirigiram sua frustração e raiva aos "oportunistas" associados ao que eles freqüentemente chamavam de "partido oficial". Estes, ligados aos moderados Conservadores em torno de Honório, fortalecidos com a adesão daqueles que temiam perder poder, recorreriam até mesmo à minoria Liberal para se sustentar. Após a morte de Honório, em 1856, o imperador buscou reproduzir seu sucesso, oferecendo poder em troca de submissão em sucessivos gabinetes, até que Conservadores moderados e aliados Liberais se metamorfosearem na Liga Progressista, que incorporou em suas origens essa fórmula, adotada por muitos de seus estadistas. ${ }^{36}$

É uma ironia histórica o fato de a estratégia do imperador sustentar um processo eleitoral crescentemente corrupto, o fortalecimento do executivo e as administrações efêmeras, enquanto também impulsionava a mobilização das alas radicais dos dois partidos tradicionais. A ala esquerda dos Liberais via, nesse período, a materialização de seu pesadelo político: o imperador, como seu pai, estava emergindo como uma força para o absolutismo pelo abuso de seu papel constitucional. Em 1860, Otoni retornara de seu auto-exílio político a fim de liderar uma nova geração para a reforma constitucional por meio de uma crescente mobilização política urbana entre a emergente classe média e os empreendedores de base urbana. Na mesma data, os saquaremas e seus herdeiros estavam se mobilizando para recuperar a legitimidade da ordem parlamentar representativa, censurando os moderados e seus seguidores por uma corrupção oportunista. Enquanto os Liberais culpavam o imperador pela corrupção do governo parlamentar partidário, os Conservadores, limitados por sua identificação com o monarca, geralmente o poupavam de ataques diretos; assim, atacavam seus gabinetes, pela falta de credibilidade representativa e pela deslealdade para com o partido e o parlamento, bem como requeriam as reformas eleitorais para legitimar o governo parlamentar novamente.

Seriam necessárias as pressões do imperador pela promoção da abolição gradual da escravidão e pela Guerra da Tríplice Aliança para dar relevo a tais tendências na crise política de 1868 . Nesse ano, o imperador, desesperado para vencer a guerra, descartaria seu instrumento, a Liga Progressista, e introduziria a ala saquarema dos Conservadores, para 
são como aqueles transmitidos por seu filho, ver, Ribeiro, Apontamentos, p.66-69. Grande parte disso veio à tona nas respostas do último gabinete saquarema de 1868-1870, liderado por Rodrigues Torres, então Visconde de Itaboraí, quando o gabinete entrou em conflito com o imperador acerca do abolicionismo do monarca. Ver [Paulino José Soares de Sousa, filho] ao IIImo. e Exmo. Sr. Visconde de Itaboray, s.p., s.d. [provavelmente Rio, início de 1870]. IHGB, AVU, lata 10, pasta 1, n.85 (cf. idem, Annaes do parlamento brazileiro: Camara dos Srs. Deputados. (1876-1884). T.II. Rio de Janeiro: Hypolito José Pinto, et al., 1860, p.6168, 6 de julho). Note-se que o filho de Uruguay, em suas respostas a essa crise do gabinete, foi fiel à doutrina publicada por seu pai (ver Uruguay, Visconde do. [Paulino José Soares de Sousa]. Ensaio sobre o direito administativo. 2 Volumes. Rio de Janeiro: Nacional, 1862, vol.2, p.33-34, p.55, p.7879, p.89, p.96-100), sobre a relação adequada entre o monarca e um gabinete que discordava de suas politicas. Sobre as tentativas dos Conservadores de organizar e manter a fidelidade no nivel local nesse periodo, ver Visconde do Uruguay a Joaquim Pedro de Melo, [Rio], [c. junho 1863], citado em SOUZA, J.A. Soares de. A vida do visconde do Uruguai (1807-1866): Paulino José Soares de Souza. São Paulo: Nacional, 1944, p.619; Paulino José Soares de Souza, filho a Primo e amo. [Francisco Belisário Soares de Souza], Novo Friburgo, 7 de janeiro de 1862. IHGB, Coleção Francisco Belisário, lata 277, pasta 71, no.1; Idem, Cantagalo, 24 de junho de 1863. IHGB, Coleção Francisco Belisário, lata 277, pasta 71, n. 21; Idem, [Rio], 14 de abril de 1865. IHGB, Coleção Francisco Belisário, lata 277, pasta 71, n.4. Sobre as origens e as caracteristicas da Liga Progressista, ver NABUCO, Joaquim. Um estadista do Império. Nabuco de Araujo: sua vida, suas opiniões, sua época. 3 Volumes. Rio de Janeiro: Garnier, s.d. [1897-1899], vol.2, p.75-76, p.8294, p.99-100, p.102; SILVA, João Manoel Pereira da. Memorias do meu tempo. 2 volumes. Rio de Janeiro: Garnier, 1895-1896, vol.1, p.316-317, p.320; e a correspondência citada em Mascarenhas, Um jornalista, cap.13.

37

Sobre a questão deste último parágrafo, que discute o período posterior ao enfoque sobre o qual fui solicitado pelo Almanack, faço um resumo da complexa narrativa e análise em NEEDELL, Jeffrey D. The Party of Order: The Conservatives, the State, and Slavery in the Brazilian Monarchy, 18311871. Stanford: Stanford University, 2006, caps. 6, 7. 0 leitor pode consultá-los para encontrar as referências necessárias. satisfazer Caxias, seu melhor general, que não confiava no apoio político da Liga. Esse visível exercício de poder pessoal lançou a Liga Progressista para o campo Liberal, tornando-a um radicalizado partido de oposição. Isso também conduziria os saquaremas de volta a uma posição em que tinham de enfrentar o imperador contra seu projeto abolicionista. Diferentemente da Liga, os saquaremas se recusaram a apoiar esse projeto quando o imperador os pressionou em 1868, 1869 e 1870. Nesse último ano, entretanto, com a guerra encerrada, o imperador não mais precisava deles e os retirou do poder para encontrar um gabinete mais conciliador. Depois que o efêmero gabinete do Visconde de São Vicente se desfez, Rio Branco aceitou a presidência de um novo ministério e o projeto abolicionista do imperador, arranjando um gabinete e uma maioria na Câmara, à custa da coerência e unidade partidária. Os saquaremas foram quase reduzidos a uma minoria dissidente entre os deputados Conservadores, e o partido, internamente dividido, se fracionou entre poder e princípio nos debates constitucionalistas sobre a abolição gradual imposta a eles pelo monarca e por Rio Branco em 1871.37

Tal divisão, geralmente associada à questão-chave da escravidão, seria lugar-comum de ambos os partidos pelo resto do período monárquico. Para os radicais dos dois dos partidos, como fora o caso desde 1840, o papel do imperador provocaria transformação partidária e um profundo ceticismo para com o regime que frutificaria ao longo dos vinte anos seguintes. A principal diferença entre a era anterior a 1868-1871 e a que a sucedeu é a fé dos saquaremas na Monarquia que finalmente desmoronou, assolada por repetidos golpes do próprio monarca, precisamente na época em que a mobilização popular acerca de profundas reformas sociais ameaçaria o regime, mudando dramaticamente a natureza da vida política.

Tradução: Fernanda Trindade Luciani 